\title{
Antagonistic interactions between predator and prey: mobbing of jaguars (Panthera onca) by white-lipped peccaries (Tayassu pecari)
}

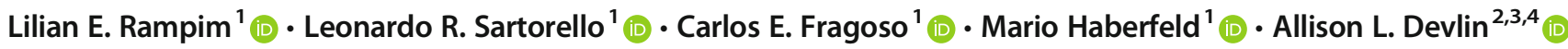

Received: 12 November 2019 /Revised: 12 December 2019 / Accepted: 19 December 2019/Published online: 6 February 2020

(C) The Author(s) 2020

\begin{abstract}
Ambush predators rely on stealth to successfully secure prey. Mobbing is a rarely observed anti-predation strategy used by groupliving prey species whereby several individuals distract or harass a predator until it either ends the pursuit or leaves the area. Herein, we present three unique cases of white-lipped peccaries (Tayassu pecari) mobbing jaguars (Panthera onca) in the wild. White-lipped peccaries and jaguars co-occur within the study area, a large-scale ecotourism and working cattle ranch in the Brazilian Pantanal. Two cases of mobbing were recorded by video camera trap during routine surveys, and a third case was directly observed by one of the authors during telemetry triangulation of a GPS-collared individual jaguar. Our observations provide direct empirical evidence of antagonistic behavioral interactions between jaguars and white-lipped peccaries that have previously been limited to anecdotes within academic literature. We discuss the implications of this behavioral interaction for the proximate and ultimate fitness of both predator and prey.
\end{abstract}

Keywords Mobbing $\cdot$ Pantanal $\cdot$ Panthera onca $\cdot$ Predator $\cdot$ Prey $\cdot$ Tayassu pecari

Ambush predators rely on stealth and cover to successfully procure prey. In group-living prey species, predator recognition and anti-predation behaviors provide direct advantages for individual and group survival (Curio et al. 1978). Commonly observed pursuit-deterrence behaviors include alarm calls, vigilance, and defensive guarding of young (Lima and Dill 1990; White and Berger 2001; Ferrari et al. 2008). Mobbing occurs when individuals or members of a

Electronic supplementary material The online version of this article (https://doi.org/10.1007/s10211-020-00335-w) contains supplementary material, which is available to authorized users.

Allison L. Devlin

adevlin@panthera.org

1 Associação Onçafari, R. Ferreira de Araújo, 221/225-Cj.14, São Paulo, SP 05428-000, Brazil

2 Panthera, 8 West 40th Street, 18th Floor, New York, NY 10018, USA

3 Department of Environmental and Forest Biology, SUNY College of Environmental Science and Forestry, 1 Forestry Drive, Syracuse, NY 13210, USA

4 Wildlife Biology Program, W.A. Franke College of Forestry and Conservation, University of Montana, NS 205, Missoula, MT 59812, USA group physically attack or harass a predator until it is distracted enough to end a pursuit or leave the area (Curio 1978; Curio et al. 1978; Dugatkin and Godin 1992). Prior studies have reported anti-predator and mobbing behaviors by primates (Iwamoto et al. 1996; Barros et al. 2002; Coss et al. 2005; Lloyd et al. 2006; Mourthé 2011; Tórrez et al. 2012; Wilcox et al. 2016), birds (Azevedo and Young 2006; Mo et al. 2016), and ungulates (Croes et al. 2006).

White-lipped peccaries (Tayassu pecari; hereafter, WLP) are group-living Neotropical ungulates that range over a mosaic of forested and open habitat from southeastern Mexico through northern Argentina (Keuroghlian et al. 2013). WLP are classified as vulnerable by the IUCN due to habitat loss, hunting pressure, and conflict with livestock (Altrichter et al. 2012; Keuroghlian et al. 2013). Currently listed as near threatened and the largest felid in the Western Hemisphere, jaguars (Panthera onca) share a similar range of distribution with WLP throughout Central and South America (Quigley et al. 2017). Jaguars are solitary apex predators that specialize in ambush predation and have a flexible diet of over 85 different species including WLP (Sunquist and Sunquist 1989; Foster et al. 2010). Observations of mobbing by WLP against jaguars are rare, likely due to the elusive nature of both species (Perry 1970). Herein, we provide empirical evidence — and discuss 
the proximate and ultimate implications - of three case studies where WLP mobbed jaguars in the southern Pantanal, Brazil.

The Brazilian Pantanal is the largest inland tropical wetland in the world. Covering around $140,000 \mathrm{~km}^{2}$, over $95 \%$ of this vast floodplain is privately owned and used for cattle ranching (Alho et al. 1988). Within the southern Pantanal, jaguars occur in densities of about 6.70 individuals per $100 \mathrm{~km}^{2}$ (Soisalo and Cavalcanti 2006). WLP are prevalent in intact or minimally fragmented habitat and typically occur in groups of 150-200 individuals. Within the southern Pantanal, the Caiman Ecological Refuge (Refúgio Ecológico Caiman, Miranda, MS, Brazil) is a working ranch that follows "jaguar-friendly" best practices which include sustaining native wildlife populations and jaguar-based ecotourism (Quigley et al. 2015).

Resident populations of individual jaguars (identified by unique rosette patterns) and herds of WLP were studied in Caiman for projects on movement ecology, habitat use, and demography. From 2013 to present, we recorded 40 observations where, upon seeing WLP (and regardless of whether or not the peccaries exhibited mobbing behavior), an individual jaguar fled the area or climbed a nearby tree. The three mobbing events presented herein were collected from video records and direct observations gathered from 2016 to 2017. Motion-activated video camera traps (Bushnell Trophy Cam Aggressor Brown, KS, USA) were programmed to record $30 \mathrm{~s}$ videos, with $1 \mathrm{~s}$ time intervals between videos.

The first mobbing event was recorded during routine camera trap surveys in the study area. Camera traps were set in the lower branches of selected trees to monitor the territorial marking behavior of jaguars (e.g., Marnewick et al. 2006). During the survey (06 October-23 November 2016), jaguars visited a particular tree 69 times, and groups of WLP were recorded around the tree base a total of 162 times (Table 1). A series of 19 videos documented an antagonistic event from 08:44 h on 08 November to 06:09 h on November 2016, between 2 and 4 individual peccaries (per video) and an adult female jaguar (about 6 years old; F01). About 3 min prior to the mobbing event (08:41 h on 08 November 2016), F01 was accompanied by her 8-month-old male cub (C01) and she attempted to climb the tree with a capybara (Hydrochoerus hydrochaeris) carcass. The attempts to carry the capybara carcass into the tree were unsuccessful; F01 deposited the prey item out of frame of the camera trap then climbed the tree. At 08:44 h, WLP surrounded the base of the tree and displayed a series of aggressive behaviors including clacks, squeals, and raised hackles (Table 1). F01 and C01 descended the tree 3 times throughout the duration of the mobbing event. After each descent, the jaguars were driven back up the tree by the peccaries. Both jaguars were in the tree for a total of nearly $10 \mathrm{~h}$ (Fig. 1; Video 1, 2). The peccaries left the area at 05:57 h (09 November 2016). F01 finally descended the tree $(06: 09 \mathrm{~h})$, recovered the capybara carcass, and again unsuccessfully attempted to climb the tree with the carcass (06:15 h). C01 descended soon after (06:43 h), indicating that he had also remained in the tree during the mobbing event.

The second mobbing event was observed by author CEF on 01 May 2017 from 17:10 to 18:00 h. An adult female (F02) was monitored by GPS telemetry as part of a study on the movement ecology of resident jaguars. During routine triangulation, F02 was observed in a tree (Vitex cymosa (Lamiaceae)) while a group of 15 WLP surrounded the base and clacked their canines with raised hackles. The herd left at 17:52 $\mathrm{h}$ and $3 \mathrm{~min}$ later (after spending $40 \mathrm{mins}$ in the tree), F02 descended the tree then visited a nearby pond to drink water. About 2 min after F02 entered a forest patch, one peccary returned to the area, and while running with raised hackles, pursued F02 into the forest.

The third mobbing event was recorded by video camera trap on 24 September 2017 at 06:10 h (Video 3). The camera trap was placed at the entrance of a culvert located near a pond and surrounded by a marsh where peccaries commonly forage. The authors previously recorded an adult female jaguar monitored by GPS collar (F03) consuming a WLP carcass within this culvert, indicating that the structure likely provided effective security cover for the predator. During the mobbing event, F03 remained in the culvert while several WLP gathered near the entrance. F03 hissed, snarled, and bluff charged before backing further into the culvert while the peccaries clacked and grunted for the duration of the $30 \mathrm{~s}$ video.

During each mobbing event, WLP exhibited agitation and aggression (e.g., clacking canines, raised hackles, vocalizations). For WLP, the decision to engage in mobbing behavior is likely driven by group size and the degree to which individuals may be scattered over a given area. Highly social and mobile, WLP travel in groups ranging from 10 to over 300 individuals (Reyna-Hurtado et al. 2015). Larger groups can cover home ranges of up to $100 \mathrm{~km}^{2}$ (Fragoso 1998). Herds tend to follow a single dominant individual, though smaller groups may occasionally form in a fission-fusion dynamic (Reyna-Hurtado et al. 2015). Individual peccaries separated from the group are more vulnerable to predation risk. A lone peccary may benefit from using noisy behaviors (e.g., squealing, clacking canines) to alert conspecifics to the presence of a predator, after which point the group will collectively mob the predator to disrupt the predation attempt.

Jaguars are ambush predators and typically kill prey with a single bite through the skull (Schaller and Vasconcelos 1978). Jaguars prefer to consume WLP at rates above their relative abundance (Polisar et al. 2003; Crawshaw and Quigley 2002; Garla et al. 2001; Carrillo et al. 2009) and in ranches tend to predate upon fewer cattle as they increasingly predate upon peccaries (Cavalcanti and Gese 2010). This dietary preference may be due to the large group size and conspicuous foraging behavior of WLP (Perry 1970; Garla et al. 2001; Mendes Pontes and Chivers 2007). Along with the high vagility of 
Table 1 Total number of records and observed behaviors (percentage in parentheses) for videos containing only jaguars (Panthera onca), only whitelipped peccaries (Tayassu pecari), and antagonistic (mobbing) interaction between the two species

\begin{tabular}{|c|c|c|c|c|c|c|}
\hline \multirow[b]{2}{*}{ Species } & \multirow[b]{2}{*}{ Total records } & \multicolumn{5}{|l|}{ Behavior } \\
\hline & & Climb & Vigilant & Clack & Hackles & Sniff \\
\hline Panthera onca & 69 & $17(24.64)$ & $24(34.78)$ & - & - & - \\
\hline Tayassu pecari & 162 & - & - & $125(77.16)$ & $14(8.64)$ & $52(32.10)$ \\
\hline Interaction & 19 & $1(5.26)$ & $18(94.74)$ & 17 (89.47) & $10(52.63)$ & $17(89.47)$ \\
\hline
\end{tabular}

WLP (Fragoso 1998; Reyna-Hurtado et al. 2009; Jácomo et al. 2013), however, this may mean that solitary ambush predators like jaguars must also navigate a relatively risky landscape. At least three historical anecdotes exist of jaguars pursued and killed by herds of peccaries (Perry 1970). As evidenced in the third mobbing event, jaguars may use man-made structures such as culverts for security cover when evading pursuit.

Predators may indirectly experience reduced ability to capture or consume prey due to disruption caused by mobbing. The predator may need to invest additional energy into avoidance behaviors before successfully completing a predation attempt or feeding on a carcass (Polisar et al. 2003). For example, in the first event, F01 successfully killed a capybara but was prevented from consuming the carcass for nearly $22 \mathrm{~h}$ due to the mobbing peccaries. To our knowledge, there is no prior confirmed record of jaguars attempting to carry a prey item into a tree. This behavior may indicate that $\mathrm{F} 01$ attempted to mitigate the disruption in feeding caused by the mobbing WLP.

Mobbing is advantageous for prey species as multiple individuals contribute to the behavior, which aids in enemy recognition and may disrupt a predation attempt or drive the predator away from the area (Curio 1978; Curio et al. 1978; Dugatkin and Godin 1992). Clouded leopards (Neofelis nebulosa) were mobbed by leaf monkeys (Trachypithecus

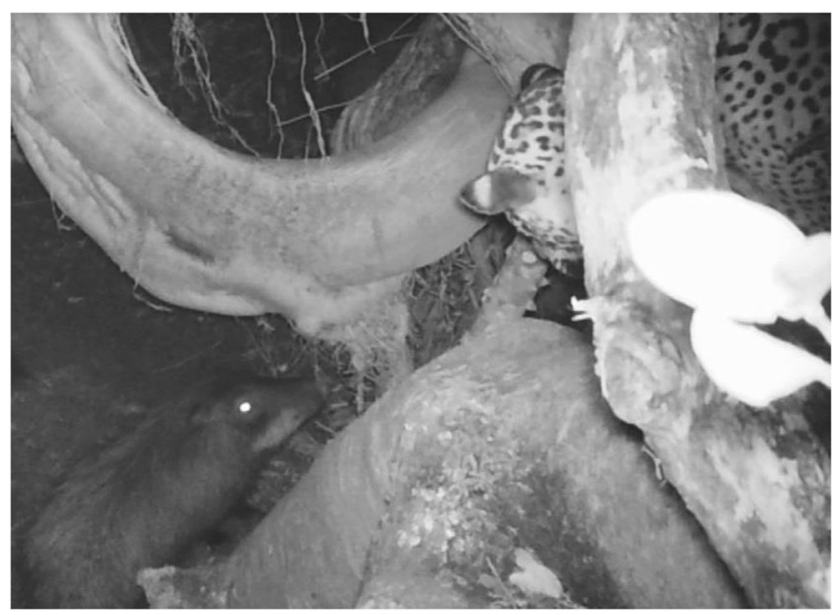

Fig. 1 Still frame from a camera trap video record of a mobbing event whereby white-lipped peccaries (left) chased female F01 (right) up a tree while her cub $(\mathrm{C} 01)$ presumably remained out of frame in the tree phayrei; Lloyd et al. 2006) and, on a single occasion, by two species of cooperating primates (gibbons, Hylobates albibarbis; langurs, Presbytis rubicunda; Wilcox et al. 2016). Groups of giant otters (Pteroneura brasiliensis) have driven jaguars from river edges (Leuchtenberger et al. 2016). The risks of aggressively engaging with a predator may sometimes outweigh the benefits, however, as in the near certain mortality of a capuchin (Cebus capucinus) that attempted to mob a jaguar (Tórrez et al. 2012).

The proximate and ultimate consequences of predation risk exerts direct selective pressure on prey species. Prey expend time and energy on vigilance or anti-predation behaviors including mobbing (Blumstein 2000; Coss and Ramakrishnan 2000). The predator experiences direct and indirect costs associated with mobbing by prey as well, including disruption in predation attempts and reduced ability to catch or consume prey. The case studies presented herein further provide direct evidence of interspecific interactions that drive complex predator-prey dynamics.

Acknowledgments We are thankful to ICMBiolCENAP (Atibaia, SP, Brazil) and Refúgio Ecológico Caiman for their partnership with Projeto Onçafari. We also thank LOG Nature and Bushnell Outdoor Products for supplying our Project with the camera traps used to conduct this research. We are particularly grateful to M. Choo, K.B. Choo, R. Bidwell, V. Bidwell, S. Woolley, and D. and E. McFarland for their invaluable support. We extend our gratitude to $\mathrm{H}$. Quigley for his helpful feedback and recommendations that improved the manuscript.

Funding information Our project was funded by Projeto Onçafari, conducted under SISBIO permit numbers 30053-7 and 30053-8, and adheres to scientific and field best practices as recommended by ICMBiolCENAP.

Open Access This article is licensed under a Creative Commons Attribution 4.0 International License, which permits use, sharing, adaptation, distribution and reproduction in any medium or format, as long as you give appropriate credit to the original author(s) and the source, provide a link to the Creative Commons licence, and indicate if changes were made. The images or other third party material in this article are included in the article's Creative Commons licence, unless indicated otherwise in a credit line to the material. If material is not included in the article's Creative Commons licence and your intended use is not permitted by statutory regulation or exceeds the permitted use, you will need to obtain permission directly from the copyright holder. To view a copy of this licence, visit http://creativecommons.org/licenses/by/4.0/. 


\section{References}

Alho CJR, Lacher T, Goncalves H (1988) Environmental degradation in the Pantanal ecosystem. Bioscience 38:164-171

Altrichter M, Taber A, Beck H et al (2012) Range-wide declines of a key Neotropical ecosystem architect, the Near Threatened white-lipped peccary Tayassu pecari. Oryx 46:87-98

Azevedo CS, Young RJ (2006) Behavioural responses of captive-born greater rheas Rhea americana Linnaeus (Rheiformes, Rheidae) submitted to antipredator training. Rev Bras Zool 23:186-193

Barros M, Boere V, Mello EL, Tomaz C (2002) Reactions to potential predators in captive-born marmosets (Callithrix penicillata). Int $\mathrm{J}$ Primatol 23:443-454

Blumstein DT (2000) Understanding antipredatory behavior for conservation. Open Ctry:37-44

Carrillo E, Fuller TK, Saenz JC (2009) Jaguar (Panthera onca) hunting activity: effects of prey distribution and availability. J Trop Ecol 25: 563-567

Cavalcanti SMC, Gese EM (2010) Kill rates and predation patterns of jaguars (Panthera onca) in the southern Pantanal, Brazil. J Mammal 91:722-736

Coss RG, Ramakrishnan U (2000) Perceptual aspects of leopard recognition by wild bonnet macaques (Macaca radiata). Behaviour 137: 315-335

Coss RG, Ramakrishnan U, Schank J (2005) Recognition of partially conceal leopards by wild bonnet macaques (Macaca radiata): the role of the spotted coat. Behav Proc 68:145-163

Crawshaw PG, Quigley HB (2002) Jaguar and puma feeding habits in the Pantanal, Brazil, with implications for their management and conservation. In: Medellin et al (eds) El jaguar en el nuevo milenio. Ediciones Científicas Universitárias, Universidad Nacional Autónoma de Mexico / Wildlife Conservation Society, New York, New York, pp 223-235

Croes BM, Laurance WF, Lahm SA, Tchignoumba L, Alonso A, Lee ME, Campbell P, Buij R (2006) The influence of hunting on antipredator behavior in Central African monkeys and duikers. Biotropica 39:257-263

Curio E (1978) Adaptive significance of avian mobbing. 1. Teleonomic hypotheses and predictions. J Comp Ethol 48:175-183

Curio E, Ernst U, Vieth W (1978) Cultural transmission of enemy recognition: one function of mobbing. Science 202(4370):899-901

Ferrari MCO, Messier F, Chivers DP (2008) Can prey exhibit threatsensitive generalization of predator recognition? Extending the predator recognition continuum hypothesis. Proc R Soc B Biol Sci 275: $1811-1816$

Foster RJ, Harmsen BJ, Valdes B, Pomilla C, Doncaster CP (2010) Food habits of sympatric jaguars and pumas across a gradient of human disturbance. J Zool 280:309-318

Fragoso JMV (1998) Home range and movement patterns of white-lipped peccary (Tayassu pecari) herds in the Northern Brazilian Amazon. Biotropica 30:458-469

Garla RC, Setz EZF, Gobbi N (2001) Jaguar (Panthera onca) food habits in Atlantic Rain Forest of southeastern Brazil. Biotropica 33:691696

Jácomo AT de A, Furtado MM, Kashivakura CK, Marinho-Filho J, Sollmann R, Torres NM, Silveira L (2013) White-lipped peccary home-range size in a protected area and farmland in the central Brazilian grasslands. J Mammal 94:137-145

Keuroghlian A, Desbiez A, Reyna-Hurtado R, Altrichter M, Beck H, Taber A, Fragoso JMV (2013) Tayassu pecari. The IUCN Red List of Threatened Species

Dugatkin LA, Godin J-GJ (1992) Prey approaching predators: a costbenefit perspective. Ann Zool Fennici 29:233-252
Iwamoto T, Mori A, Kawai M, Bekele A (1996) Anti-predator behavior of gelada baboons. Primates 37:389-397

Leuchtenberger C, Almeida SB, Andriolo A, Crawshaw PG (2016) Jaguar mobbing by giant otter groups. Acta Ethol 19:143-146

Lima SL, Dill LM (1990) Behavioral decisions made under the risk of predation: a review and prospectus. Can J Zool 68:619-640

Lloyd E, Kreetiyutanont K, Prabnasuk J et al (2006) Observation of Phayre's leaf monkeys mobbing a clouded leopard at Phu Khieo Wildlife Sanctuary (Thailand). Mammalia 70:158-159

Marnewick KA, Bothma JD, Verdoorn GH (2006) Using cameratrapping to investigate the use of a tree as a scent-marking post by cheetahs in the Thabazimbi district. South African J Wildl Res 36: 139-145

Mendes Pontes AR, Chivers DJ (2007) Peccary movements as determinants of the movements of large cats in Brazilian Amazonia. J Zool 273:257-265

Mo M, Waterhouse DR, Hayler P, Hayler A (2016) Observations of mobbing and other agonistic responses to the Powerful Owl Ninox strenua. Aust Zool 38:43-51

Mourthé Í (2011) Reactions of white-bellied spider monkeys to a predation attempt by a cougar. Neotrop Primates 18:28-29

Perry R (1970) The world of the jaguar. Taplinger Publishing Company, New York

Polisar J, Maxit I, Scognamillo D, Farrell L, Sunquist ME, Eisenberg JF (2003) Jaguars, pumas, their prey base, and cattle ranching: ecological interpretations of a management problem. Biol Conserv 109: 297-310

Quigley H, Hoogesteijn R, Hoogesteijn A, Foster R, Payan E, Corrales D, Salom-Perez R, Urbina Y (2015) Observations and preliminary testing of jaguar depredation reduction techniques in and between core jaguar populations. Parks 21:63-72

Quigley H, Foster R, Petracca L, Payan E, Salom R, Harmsen B (2017) Panthera onca. The IUCN Red List of Threatened Species

Reyna-Hurtado AR, Rojas-Flores E, Tanner GW (2009) Home range and habitat preferences of white-lipped peccaries (Tayassu pecari) in Calakmul, Campeche, Mexico. J Mammal 90:1199-1209

Reyna-Hurtado R, Beck H, Altrichter M, Chapman CA, Bonnell TR, Keuroghlian A, Desbiez AL, Moreira-Ramirez JF, O'Farrill G, Fragoso J, Naranjo EJ (2015) What ecological and anthropogenic factors affect group size in white-lipped peccaries (Tayassu pecari)? Biotropica 48:246-254

Schaller GB, Vasconcelos JMC (1978) Jaguar predation on capybara. Z Saeugetierk 43:296-301

Soisalo MK, Cavalcanti SMC (2006) Estimating the density of a jaguar population in the Brazilian Pantanal using camera-traps and capturerecapture sampling in combination with GPS radio-telemetry. Biol Conserv 129:487-496

Sunquist ME, Sunquist FC (1989) Ecological constraints on predation by large felids. In: Gittleman JL (ed) Carnivore behavior, ecology and evolution. Cornell University Press, New York, pp 283-381

Tórrez L, Robles N, González A, Crofoot MC (2012) Risky business? Lethal attack by a jaguar sheds light on the costs of predator mobbing for capuchins (Cebus capucinus). Int J Primatol 33:440-446

White KS, Berger J (2001) Antipredator strategies of Alaskan moose: are maternal trade-offs influenced by offspring activity? Can J Zool 79: 2055-2062

Wilcox CH, Supiansyah, Abdul Azis K, Zainuddin J, Rahman, Cheyne SM (2016) Predator mobbing and interspecies cooperation: an interaction between gibbons, langurs and a clouded leopard. Asian Primates J 6:20-26

Publisher's note Springer Nature remains neutral with regard to jurisdictional claims in published maps and institutional affiliations. 